\title{
Phytoplankton from Vam Co River in Southern Vietnam
}

\author{
Thanh-Son Dao (Corresponding author) \\ Hochiminh City University of Technology \\ 268 Ly Thuong Kiet Street, District 10, Hochiminh City, Vietnam \\ Tel: 84-838-639-682 Email: dao.son@ @cmut.edu.vn \\ Thi-Nhu-Phuong Bui \\ Institute for Environment and Resources \\ 142 To Hien Thanh Street, District 10, Hochiminh City. Vietnam. \\ Tel: 84-838-651-132Ｅmail: buinhuphuong@yahoo.com
}

Received: December 25, 2015 Accepted: January 17, 2016

doi:10.5296/emsd.v5i1.8775 URL: http://dx.doi.org/10.5296/emsd.v5i1.8775

\begin{abstract}
In this study we investigated the variation of phytoplankton and the water quality in Vam Co River, Southern Vietnam. Phytoplankton were bi-monthly monitored in 2011 at 12 sampling sites in the river. Some basic environmental parameters were also monitored including temperature, $\mathrm{pH}$, turbidity, inorganic nitrogen and dissolved phosphorus. The phytoplankton biodiversity and Diatomeae indices were applied for environmental quality evaluation. The results showed that temperature ranged from $28.7-31.9{ }^{\circ} \mathrm{C}$ during the monitoring. The $\mathrm{pH}$ and turbidity were in between $3.9-7.0$ and $2-64$ NTU, respectively. The nitrate and ammonium concentrations were from $0.06-1.21$ and $0.03-1.15 \mathrm{mg} / \mathrm{L}$, respectively. The phosphate concentration was between 0.02 and $0.37 \mathrm{mg} / \mathrm{L}$. The environmental parameters were favorable for phytoplankton development. The phytoplankton analyses showed that there were 290 species of diatoms, green algae, golden algae, yellow algae, euglenoids, dinoflagellates and cyanobacteria of which green algae and diatoms were dominant in species number. Phytoplankton density ranged from 920 - 383600 individuals/L with the main dominant species of diatoms. The biodiversity index values during the monitoring were from 0.15 - 3.80 characterized for oligotrophic to eutrophic conditions whereas the Diatomeae index values were more than 0.2 indicating for the eutrophic characteristic of the aquatic environment. Besides, phytoplankton species number positively correlated with temperature but negatively correlated with nitrate concentration. Additionally, the biodiversity positively
\end{abstract}


correlated with temperature and species number, but negatively correlated with nitrate and phytoplankton abundance. The results confirmed the advantage of using phytoplankton and their indices for environmental monitoring and water quality assessment.

Keywords: Vam Co River, Phytoplankton, Biological indices, Correlation, Nutrients, Water quality

\section{Introduction}

Phytoplankton are the most common organisms on the earth and widely distribute in many different environmental conditions such as water, soil, air, on trees. However, they mostly present and well develop in aquatic habitats including lakes, ponds, reservoirs, rivers, streams and oceans (Horne and Goldman 1994). The freshwater phytoplankton are composed of almost major taxonomic groups of algae and cyanobacteria (Wetzel 2001). Being primary producer, phytoplankton play a key role in aquatic ecosystem. Phytoplankton liberate the most amount of oxygen to the air via their photosynthesis and are essential part of the geo-bio-chemical cycle which make the flow of matter and energy become continuously (Horne and Goldman 1994).

Many environmental factors interact to regulate spatial and seasonal growth and succession of phytoplankton (Wetzel 2001). Temperature strongly influences on phytoplankton development and different phytoplankton group would have different optimized temperature. The $\mathrm{pH}$ is important for present and distribution of phytoplankton for example the $\mathrm{pH}$ below 4 would prevent the existence of cyanobacteria in water bodies (Dao 2010). The turbidity or transparency reflects the capacity of light intensity being able to deeply get into the water consequently the phytosynthesis and distribution of phytoplankton in water column. Nutrients including dissolved nitrogen and phosphorus are important for growth of phytoplankton and favorable for their mass development. Besides, trace elements such as iron, magnesium, copper are essential for phytoplankton because the elements could strongly stimulate or inhibit their growth (Wetzel 2001). Celekli et al. (2015) reported that phytoplankton seemed to be strictly associated with temporal variation of environmental variables in water bodies.

Phytoplankton could be used as bio-indicators for water quality and ecosystem health (Cimdins et al. 1995; APHA 2005). Besides, indices based on phytoplankton such as biodiversity, similarity, Diatomeae, among others are useful for water quality and ecological health evaluation. Kelly and Whitton (1995) suggested the diatom index (Diatomeae) was an excellent indicator for eutrophic monitoring in river. Phytoplankton morphological classification was considered as a good tool to reflect the water quality from Nile River (Saad and El-Karim 2015).

In Vietnam, a variety of investigations have been conducted focusing on morphological biodiversity of phytoplankton (Pham 1969; Nguyen 1997; Duong 1996; Nguyen 2003; Phung et al. 1994; Nguyen et al. 2007). However, publications on interaction between phytoplankton and environmental parameters and water quality based on phytoplankton from rivers in Vietnam are limited. Tran et al. (2015) found the variation of phytoplankton abundance between dry and rainy seasons. Besides, the authors reported there was a 


\section{Macrothink Institute ${ }^{\text {TM }}$}

significant relation between phytoplankton abundance and inorganic nitrogen and water temperature. However, the chlorophyll content of phytoplankton only regulated by the $\mathrm{pH}$ in Tuyen Lam Reservoir (Tran et al. 2015). Additionally, Duong et al. (2013) observed the water temperature and phosphate concentration influenced on cyanobacterial density in Nui Coc reservoir. In this study we investigated the variation of phytoplankton as well as the water quality based on phytoplankton in Vam Co River in Southern Vietnam.

\section{Materials and Methods}

\subsection{Study Area and Sample Collection}

Vam Co river consists of two branches, Vam Co Dong and Vam Co Tay Rivers, which are both originated from Cambodia (Fig. 1). Vam Co Dong and Vam Co Tay Rivers have the length of around 270 and $185 \mathrm{~km}$, respectively. They are both located within the Long An Province, Southern Vietnam. Then the Vam Co Tay and Vam Co Dong Rivers join together in Tan Tru District, Long An Province to become Vam Co river before running into the Indochina Sea. The Vam Co River is around $40 \mathrm{~km}$ long (Le 2009). Currently, Vam Co Dong and Vam Co Tay Rivers have been received many different effluents from industrial, agricultural and domestic activities by human beings.

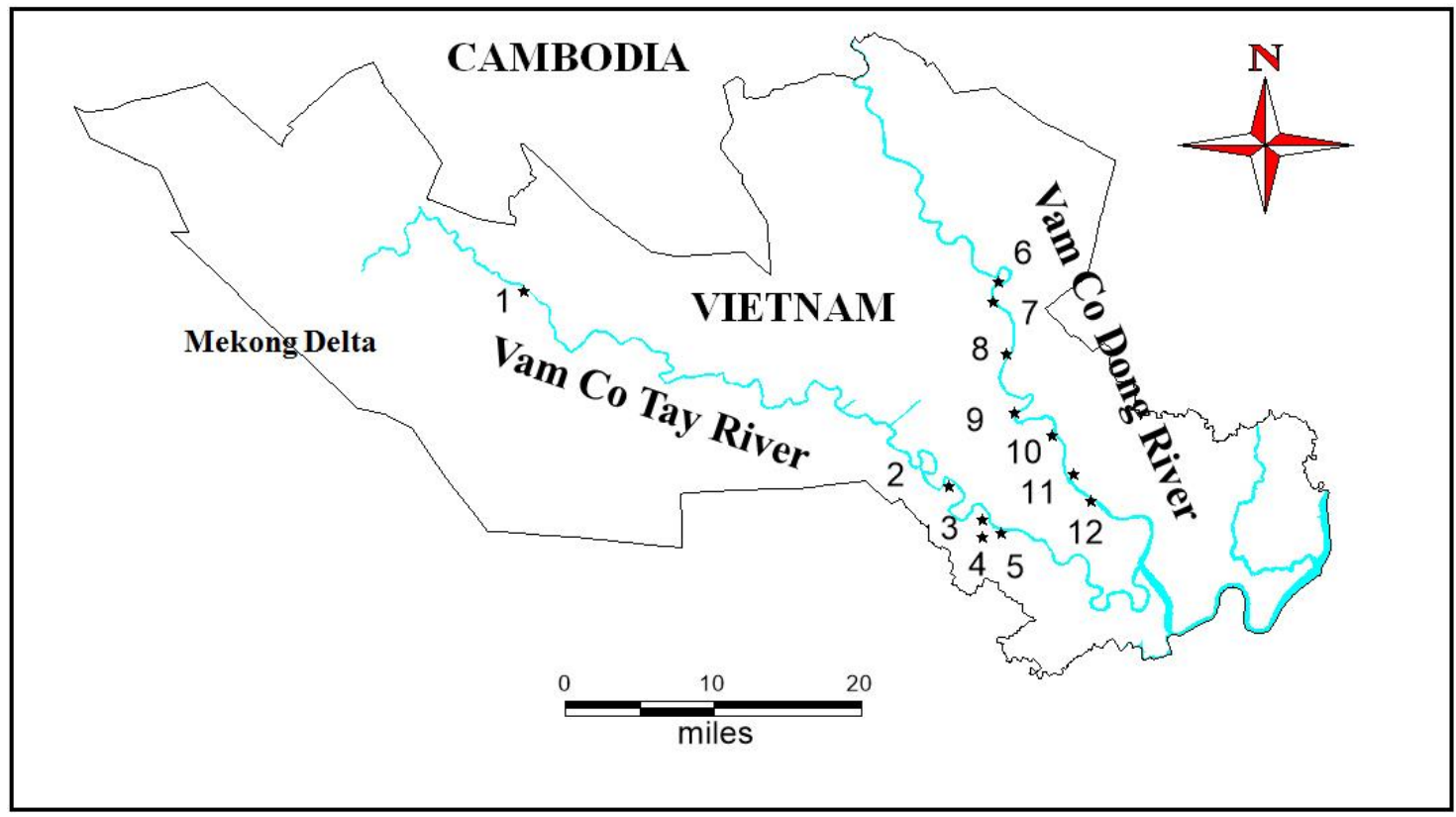

Figure 1. Vam Co River consisting 2 branches, Vam Co Dong River and Vam Co Tay River with 12 sampling sites (numbers 1-12)

In Vam Co River, samples of qualitative and quantitative phytoplankton at 12 sites were collected and fixed with Lugol solution (Sournia 1978) in February, May, July, August and October 2011 (Fig. 1; Table 1). Besides, surface water was also collected for nutrient $\left(\mathrm{N}_{-} \mathrm{NH}_{4}{ }^{+}, \mathrm{N}-\mathrm{NO}_{3}{ }^{-}, \mathrm{P}_{-} \mathrm{PO}_{4}{ }^{3-}\right)$ analyses in the laboratory. The water samples were collected in the surface and kept on ice until analyzed in the laboratory. 
Table 1. Coordinates and locations of the sampling sites

\begin{tabular}{|c|l|c|c|}
\hline Sampling sites & \multicolumn{1}{|c|}{ Local names } & Longitude $(\mathrm{N})$ & Latitude (E) \\
\hline 1 & Moc Hoa town & $10^{\circ} 46.42 .82$ & $105^{\circ} 56.36 .55$ \\
\hline 2 & Thu Thua creek - Vam Co Tay & $10^{\circ} 35.14 .60$ & $106^{\circ} 22.24 .00$ \\
\hline 3 & Tan An bridge & $10^{\circ} 33.03 .54$ & $106^{\circ} 24.26 .00$ \\
\hline 4 & Chu Tiet station & $10^{\circ} 32.27 .77$ & $106^{\circ} 25.10 .15$ \\
\hline 5 & Moi bridge & $10^{\circ} 32.13 .73$ & $106^{\circ} 24.36 .15$ \\
\hline 6 & An Ha creek & $10^{\circ} 47.21 .50$ & $106^{\circ} 24.36 .15$ \\
\hline 7 & Cau Tau market & $10^{\circ} 47.38 .20$ & $106^{\circ} 25.42 .90$ \\
\hline 8 & Xang creek & $10^{\circ} 43.31 .46$ & $106^{\circ} 25.47 .38$ \\
\hline 9 & Thu Thua creek - Vam Co Dong & $10^{\circ} 38.41 .86$ & $106^{\circ} 26.28 .28$ \\
\hline 10 & Ben Luc bridge & $10^{\circ} 38.21 .05$ & $106^{\circ} 28.21 .14$ \\
\hline 11 & Chanh creek & $10^{\circ} 36.40 .80$ & $106^{\circ} 29.30 .90$ \\
\hline 12 & Doi Ma creek & $10^{\circ} 34.70 .10$ & $106^{\circ} 30.51 .80$ \\
\hline
\end{tabular}

\subsection{Physical, Chemical and Phytoplankton Analyses}

Physical parameters were measured in situ such as temperature and $\mathrm{pH}$ (WTW 350i) and turbidity (Hach DR/2800). Nutrients in surface water were analyzed colorimetrically with a spectrophotometer (Hach DR/2800) according to APHA (2005). The detection limits of nutrient parameters were $0.02\left(\mathrm{~N}^{-N_{3}}{ }_{3}^{-}\right), 0.02\left(\mathrm{~N}_{-} \mathrm{NH}_{4}{ }^{+}\right)$, and $0.02 \mathrm{mg} / \mathrm{L}$ for orthophosphate $\left(\mathrm{P}-\mathrm{PO}_{4}{ }^{3-}\right)$.

Phytoplankton was observed at 400 - 800X magnification (Olympus BX51 microscope). Identification was based on morphology following the system of Komárek and Anagnostidis (1989, 1999, 2005) for cyanobacteria, Krammer and Lange-Bertalot (2004a, b) for diatoms, Presscot (1951) and Bourrelly (1970) for green algae and other taxonomy books for golden and yellow algae, dinoflagellates and euglenoids. Phytoplankton density was enumerated with a Sedgewick-Rafter counting chamber according to Sournia (1978).

\subsection{Data Analysis}

The biodiversity index (H') was calculated based on the phytoplankton quantitative data, to evaluate the diversity of the algal communities and to assess the impacts of environmental factors and human activities on the organisms.

S

$$
\begin{aligned}
& \mathrm{H}^{\prime}=-\sum \text { pi } \log _{2} \text { pi } \quad \text { (Sournia 1978) } \\
& \mathrm{i}=1
\end{aligned}
$$

where pi: the ratio of the number of species i over the total number of all phytoplankton

The Diatomeae Index was calculated based on the species richness of the Centrales and Pennales orders of Diatoms. This index value revealed the the trophic condition of water bodies. 


\section{Macrothink}

Diatomeae index $=\mathrm{C} / \mathrm{P}($ Nguyen 2003)

where: C: species number of Centrales

P: species number of Pennales

The Pearson test (SPSS, version 16.0) was used for calculation on the correlation between phytoplankton (species number, abundance and biodiversity index) and environmental parameters in Vam Co river.

\section{Results}

Temperature of surface water during the monitoring times ranged from $28.7-31.9{ }^{\circ} \mathrm{C}$, quite stable among the sampling sites and through out the year (Table 2). The $\mathrm{pH}$ and turbidity ranged from were in between $3.9-7.0$ and $2-64$ Nephelometric Turbidity Unit (NTU), respectively. Both $\mathrm{pH}$ and turbidity in Vam Co Dong River were much lower than those in Vam Co Tay River.

The nitrate and ammonium concentrations in Vam Co Tay River were from $0.06-1.1 \mathrm{mg} / \mathrm{L}$ and $0.03-1.15 \mathrm{mg} / \mathrm{L}$, respectively. Those in Vam Co Dong River valued of $0.13-1.21 \mathrm{mg} / \mathrm{L}$ and $0.03-0.79 \mathrm{mg} / \mathrm{L}$, respectively. The phosphate concentration was from $0.02-0.37 \mathrm{mg} / \mathrm{L}$ in Vam Co Tay River, and $0.02-0.08$ mg/L in Vam Co Dong River (Table 2).

Table 2. Physical and chemical parameters from Vam Co River during 2011. Data were presented as minima to maxima and mean values (in parentheses). Temp, temperature.

\begin{tabular}{|c|c|c|c|c|c|c|c|}
\hline Sites & Local names & Temp. $\left({ }^{\circ} \mathrm{C}\right)$ & $\mathrm{pH}$ & $\begin{array}{l}\text { Turbidity } \\
\text { (NTU) }\end{array}$ & $\begin{array}{c}\mathrm{N}^{-\mathrm{NH}_{4}}{ }^{+} \\
(\mathrm{mg} / \mathrm{L})\end{array}$ & $\begin{array}{l}\mathrm{N}^{-\mathrm{NO}_{3}}{ }^{-} \\
(\mathrm{mg} / \mathrm{L})\end{array}$ & $\begin{array}{l}\mathrm{P}_{-} \mathrm{PO}_{4}{ }^{3-} \\
(\mathrm{mg} / \mathrm{L})\end{array}$ \\
\hline 1 & Moc Hoa town & $\begin{array}{c}30.0-31.9 \\
(30.9)\end{array}$ & $\begin{array}{c}6.4-7.0 \\
(6.8) \\
\end{array}$ & $15-64(34)$ & $\begin{array}{c}0.04-1.15 \\
(0.48)\end{array}$ & $\begin{array}{c}0.06-0.64 \\
(0.31)\end{array}$ & $\begin{array}{c}0.08-0.16 \\
(0.11)\end{array}$ \\
\hline 2 & $\begin{array}{l}\text { Thu Thua creek - } \\
\text { Vam Co Tay }\end{array}$ & $\begin{array}{c}29.5-31.0 \\
(30.3)\end{array}$ & $\begin{array}{c}6.3-6.8 \\
(6.5)\end{array}$ & $12-48(26)$ & $\begin{array}{c}0.03-0.16 \\
(0.07)\end{array}$ & $\begin{array}{c}0.16-0.66 \\
(0.35)\end{array}$ & $\begin{array}{c}0.02-0.07 \\
(0.04)\end{array}$ \\
\hline 3 & Tan An bridge & $\begin{array}{c}29.5-30.7 \\
(30.2)\end{array}$ & $\begin{array}{c}6.3-6.8 \\
(6.6)\end{array}$ & $21-45(32)$ & $\begin{array}{c}0.03-0.06 \\
(0.04)\end{array}$ & $\begin{array}{c}0.13-0.75 \\
(0.45)\end{array}$ & $\begin{array}{c}0.03-0.06 \\
(0.05)\end{array}$ \\
\hline 4 & Chu Tiet station & $\begin{array}{c}29.6-30.8 \\
(30.3)\end{array}$ & $\begin{array}{c}6.3-6.8 \\
(6.6)\end{array}$ & $20-43(28)$ & $\begin{array}{c}0.03-0.08 \\
(0.05)\end{array}$ & $\begin{array}{c}0.13-1.10 \\
(0.46)\end{array}$ & $\begin{array}{c}0.03-0.07 \\
(0.06)\end{array}$ \\
\hline 5 & Moi bridge & $\begin{array}{c}30.0-30.7 \\
(30.3)\end{array}$ & $\begin{array}{c}6.5-6.9 \\
(6.8)\end{array}$ & $\begin{array}{c}10-27 \\
(20)\end{array}$ & $\begin{array}{c}0.33-0.97 \\
(0.66)\end{array}$ & $\begin{array}{c}0.11-0.45 \\
\quad(0.28)\end{array}$ & $\begin{array}{c}0.13-0.37 \\
(0.21)\end{array}$ \\
\hline 6 & An Ha creek & $\begin{array}{c}29.8-30.9 \\
(30.3)\end{array}$ & $\begin{array}{c}4.2-5.6 \\
(5.1)\end{array}$ & $10-32(22)$ & $\begin{array}{c}0.06-0.79 \\
(0.46)\end{array}$ & $\begin{array}{c}0.15-0.66 \\
(0.32)\end{array}$ & $\begin{array}{c}0.02-0.04 \\
(0.03)\end{array}$ \\
\hline 7 & Cau Tau market & $\begin{array}{c}29.1-31.1 \\
(30.3)\end{array}$ & $\begin{array}{c}4.0-5.7 \\
(4.7)\end{array}$ & $\begin{array}{l}2-39 \\
(17)\end{array}$ & $\begin{array}{c}0.04-0.23 \\
(0.15)\end{array}$ & $\begin{array}{c}0.13-0.71 \\
(0.43)\end{array}$ & $\begin{array}{c}0.02-0.03 \\
(0.03)\end{array}$ \\
\hline 8 & Xang creek & $\begin{array}{c}28.9-30.9 \\
(30.2)\end{array}$ & $\begin{array}{c}3.9-5.4 \\
(4.6)\end{array}$ & $\begin{array}{l}3-25 \\
(12)\end{array}$ & $\begin{array}{c}0.05-0.27 \\
(0.16)\end{array}$ & $\begin{array}{c}0.14-0.67 \\
(0.43)\end{array}$ & $\begin{array}{c}0.02-0.07 \\
(0.05)\end{array}$ \\
\hline 9 & $\begin{array}{l}\text { Thu Thua creek - } \\
\text { Vam Co Dong }\end{array}$ & $\begin{array}{c}28.7-30.9 \\
(30.2)\end{array}$ & $\begin{array}{c}4.6-6.1 \\
(5.6)\end{array}$ & $\begin{array}{l}5-42 \\
(19)\end{array}$ & $\begin{array}{c}0.12-0.37 \\
(0.23)\end{array}$ & $\begin{array}{c}0.16-1.02 \\
(0.55)\end{array}$ & $\begin{array}{c}0.02-0.08 \\
(0.05)\end{array}$ \\
\hline 10 & Ben Luc bridge & $29.1-30.8$ & $4.6-6.2$ & $3-44$ & $0.07-0.42$ & $0.22-1.19$ & $0.02-0.06$ \\
\hline
\end{tabular}




\begin{tabular}{|c|l|c|c|c|c|c|c|}
\hline & & $(30.1)$ & $(5.4)$ & $(22)$ & $(0.24)$ & $(0.61)$ & $(0.04)$ \\
\hline \multirow{2}{*}{11} & Chanh creek & $28.7-30.7$ & $4.4-6.4$ & $3-45$ & $0.04-0.49$ & $0.16-1.21$ & $0.03-0.05$ \\
& & $(30.1)$ & $(5.4)$ & $(19)$ & $(0.26)$ & $(0.64)$ & $(0.04)$ \\
\hline \multirow{2}{*}{12} & \multirow{2}{*}{ Doi Ma creek } & $28.7-30.9$ & $4.4-6.5$ & $6-81(27)$ & $0.03-0.44$ & $0.19-1.15$ & $0.02-0.04$ \\
& & $(30.2)$ & $(5.4)$ & & $(0.19)$ & $(0.62)$ & $(0.03)$ \\
\hline
\end{tabular}

During the six monitoring times, there were 290 algal species belonging to 7 groups of phytoplankton in the studied area. Among the phytoplankton groups, green algae and diatoms were dominant in species number with 195 species in total, gaining around $67.2 \%$ of total (Table 3). There were 46 species of euglenoids (gaining 15.8\%), 36 species of cyanobacteria (12.5\%), 7 species of golden algae (2.4\%), 4 species of dinoflagellates (1.4\%) and 2 species of yellow algae $(0.7 \%$; Table 3$)$. Generally, species number of phytoplankton was higher in rainy season and lower in dry season (Table 3). In each monitoring, species number of phytoplankton ranged from 105 (in May) to 198 (in December).

Table 3. Structure of phytoplankton communities from Vam Co River during 2011. Numbers in the table indicated the species number of each phytoplankton group.

\begin{tabular}{|l|c|c|c|c|c|c||c|c|}
\hline Phytoplankton groups & Feb & May & Jul & Aug & Oct & Dec & Total & $\%$ \\
\hline Cyanobacteria & 8 & 14 & 15 & 17 & 17 & 27 & 36 & 12.5 \\
\hline Yellow algae & 0 & 0 & 0 & 1 & 2 & 2 & 2 & 0.7 \\
\hline Golden algae & 2 & 4 & 3 & 4 & 5 & 6 & 7 & 2.4 \\
\hline Diatoms & 56 & 48 & 38 & 39 & 28 & 42 & 94 & 32.4 \\
\hline Green algae & 16 & 16 & 30 & 34 & 69 & 79 & 101 & 34.8 \\
\hline Euglenoids & 34 & 19 & 30 & 32 & 38 & 39 & 46 & 15.8 \\
\hline Dinoflagellates & 2 & 1 & 2 & 3 & 2 & 3 & 4 & 1.4 \\
\hline Total species number & 122 & 103 & 121 & 130 & 162 & 198 & 290 & 100 \\
\hline
\end{tabular}

Most of algal species and genera recorded in the river were characterized for freshwater such as Chroococcus, Microcystis, Anabaena, Mallomonas, Synura, Eunotia, Pediastrum, Micractinium, Scenedesmus, Desmids, Euglena, Phacus, Trachelomonas, Strombomonas... However, some of them originated from the estuary or coastal region like Coscinodiscus, Planktoniella, Skeletonema, Thalassiosira, Chaetoceros, Pleurosigma. Therefore, the aquatic environment in the studied area was co-affected by freshwater from inland and sea water via the tide. 


\section{$\triangle$ Macrothink}
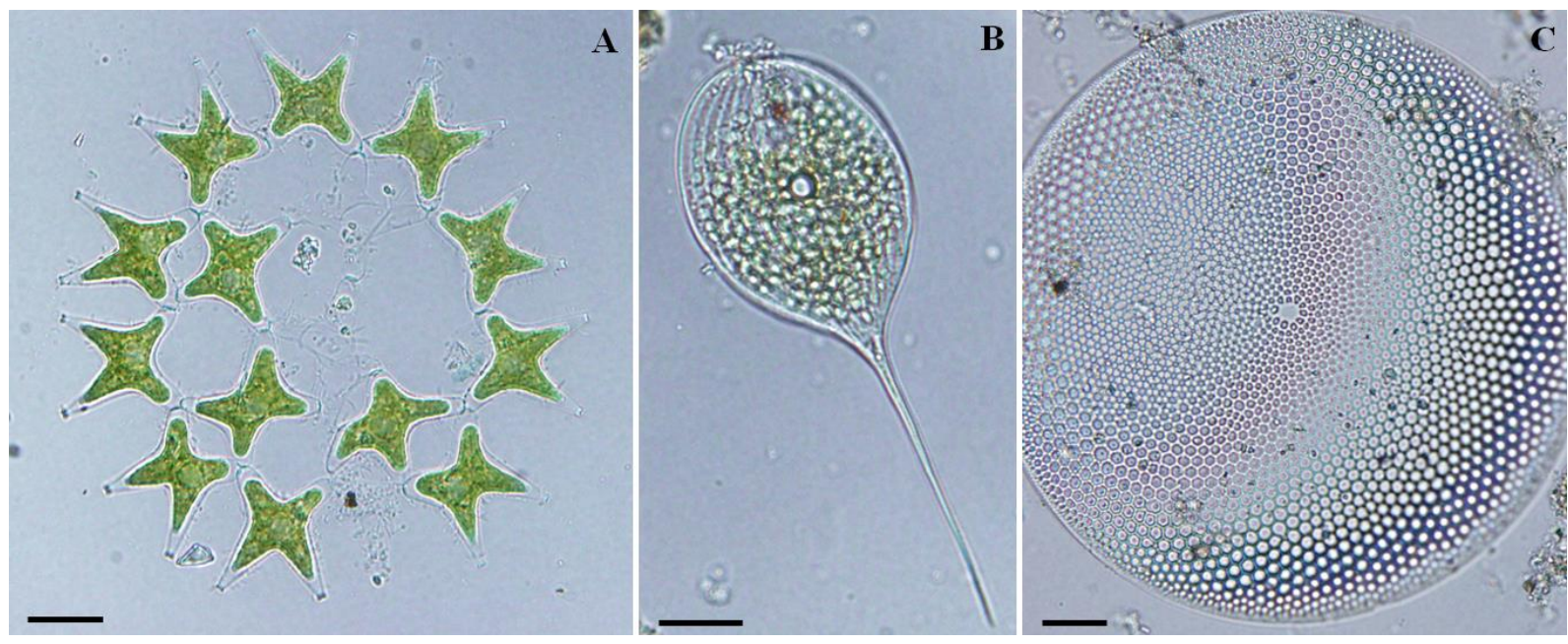

Figure 2. Some common genera of phytoplankton in the studied area. A, Pediastrum; B, Phacus; and C, Coscinodiscus. Scale bars $=20 \mu \mathrm{m}$

Phytoplankton density ranged from $920-383600$ individuals/L, lowest at the sampling site 1 (Moc Hoa Town) and highest at the site 5 (Moi bridge, Fig. 3). The dominant species in the monitored area were Cyclotella meneghiniana, Cyclotella stylorum, Eunotia spp., Desmogonium sp., Oscillatoria spp., Aulacoseira granulata, Pseudanabaena spp., Closteriopsis longissima, Lyngbya cf. hieronymusii, Dinobryon sertularia, Mougeotia sp., Trachelomonas spp. and Microcystis spp. Among the dominant species, Cyclotella meneghiniana and Eunotia spp. were dominant at most of the sampling sites.

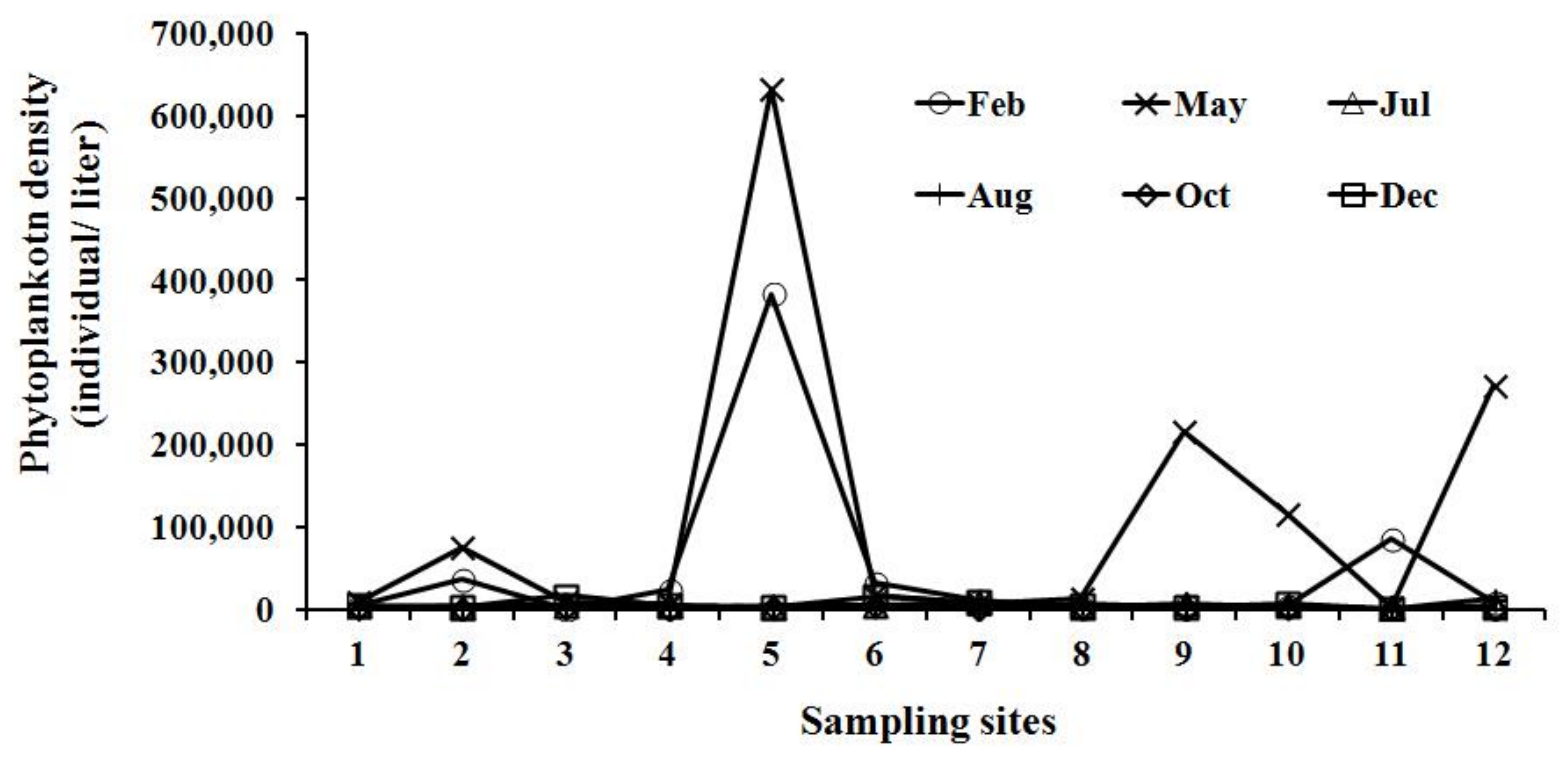

Figure 3. Phytoplankton density from Vam Co river during 2011

The values of algal biodiversity index during the monitoring in 2011 ranged from $0.15-3.80$ (Table 4). In Vam Co Tay River, from sites 1 to 5, the biodiversity index values were higher in August, October and December than in February, May and March, generally. In Vam Co Dong River, from sites $6-12$, the biodiversity index values were mostly highest in October 
and December. Besides, the index values were over 2 at the sites 1, 3 (except in December), 7 and 8 during the monitoring in 2011 (Table 4).

Table 4. Biodiversity index values (H') of phytoplankton from Vam Co River during 2011. The asterisk $\left(^{*}\right)$ indicates the eutrophic condition of the water quality at the sampling sites.

\begin{tabular}{|c|c|c|c|c|c|c|}
\hline Sampling sites & Feb & May & Jul & Aug & Oct & Dec \\
\hline 1 & 2.54 & 2.33 & 2.24 & 2.34 & 2.45 & 3.80 \\
\hline 2 & 1.01 & $0.76^{*}$ & 2.66 & 1.14 & 3.16 & 3.20 \\
\hline 3 & 2.66 & 2.14 & 2.03 & 2.76 & 3.35 & 1.46 \\
\hline 4 & 0.46 & 0.80 & 1.80 & 2.86 & 2.92 & 2.22 \\
\hline 5 & 0.15 & 2.17 & 2.05 & 2.01 & 3.30 & 2.28 \\
\hline 6 & 2.24 & $0.68^{*}$ & 2.70 & 1.96 & 3.40 & 3.07 \\
\hline 7 & 2.73 & 2.59 & 2.36 & 2.46 & 2.61 & 2.59 \\
\hline 8 & 2.61 & 2.41 & 2.32 & 2.24 & 2.80 & 3.74 \\
\hline 9 & 1.46 & 0.55 & 1.48 & 2.53 & 2.66 & 3.46 \\
\hline 10 & 1.32 & 1.29 & 2.31 & 1.49 & 3.27 & 2.25 \\
\hline 11 & 0.69 & 1.14 & 2.65 & 3.29 & 3.23 & 3.51 \\
\hline 12 & 1.40 & 0.54 & 1.95 & 0.89 & 2.89 & 3.53 \\
\hline
\end{tabular}

The Diatomeae index values were showed in table 5. Generally, there were few sites and times that the Diatomeae index values were lower than 0.2 during the six monitoring times in 2011 (Table 5).

Table 5. Diatomeae index values of phytoplankton from Vam Co River during 2011. -: N/A, The asterisk (*) indicates the values of Diatomeae index below 0.2.

\begin{tabular}{|c|c|c|c|c|c|c|}
\hline Sampling sites & Feb & May & Jul & Aug & Oct & Dec \\
\hline 1 & 0.86 & 0.27 & 0.29 & $0.15^{*}$ & 0.33 & 0.40 \\
\hline 2 & 1.13 & 0.29 & 1.00 & 0.20 & 0.25 & 0.67 \\
\hline 3 & 0.15 & $0.08^{*}$ & 0.58 & 1.00 & 0.29 & 0.50 \\
\hline 4 & 0.60 & 0.50 & 0.20 & 0.27 & 0.60 & $0.10^{*}$ \\
\hline 5 & 0.25 & - & 0.13 & 0.04 & 0.30 & 0.25 \\
\hline 6 & 0,67 & 0.43 & 0.5 & 0.50 & 0.67 & - \\
\hline 7 & 1.00 & 0.45 & 0.57 & 0.44 & 0.22 & 0.25 \\
\hline 8 & 0.20 & 0.50 & 0.33 & $0.18^{*}$ & 0.17 & 0.30 \\
\hline 9 & 0.83 & 0.63 & 0.40 & 0.6 & 0.50 & 0.30 \\
\hline 10 & 0.36 & 0.30 & 0.63 & 0.57 & 0.30 & $0.13^{*}$ \\
\hline 11 & $0.09^{*}$ & 0.43 & 0.40 & 0.29 & 0.63 & 0.42 \\
\hline 12 & 0.56 & 0.33 & 0.60 & 0.50 & 0.29 & 0.31 \\
\hline
\end{tabular}

The statistical data treatment showed that species number of phytoplankton positively correlated with temperature $(\mathrm{r}=0.368)$ and negatively correlated with nitrate concentration $(\mathrm{r}$ $=-0.628)$ in water. Besides, the biodiversity of phytoplankton positively correlated with water temperature $(r=0.443)$ and species number $(r=0.759)$. However, the biodiversity 
negatively correlated with nitrate concentration $(\mathrm{r}=-0.625)$ and phytoplankton abundance $(\mathrm{r}$ $=-0.357$; Table 6 ). Out of our expectation, the phytoplankton abundance did not correlate with any monitored environmental parameters.

Table 6: Correlation between phytoplankton (species number, abundance and bio-diversity) and environmental parameters in Vam Co River based on Pearson correlation test; r, correlation cofficient; *, $\mathrm{p}<0.05$; **, $\mathrm{p}<0.01$; ***, $\mathrm{p}<0.001$; ns, not significant $(\mathrm{p}>0.05)$; ,- N/A.

\begin{tabular}{|c|c|c|c|c|c|c|}
\hline \multirow{2}{*}{ Variables } & \multicolumn{2}{|c|}{ Species number } & \multicolumn{2}{|c|}{ Abundance } & \multicolumn{2}{|c|}{ Bio-diversity } \\
\hline & $\mathrm{r}$ & $\mathrm{p}$ & $\mathrm{r}$ & $\mathrm{p}$ & $\mathrm{r}$ & $\mathrm{p}$ \\
\hline Temperature & 0.368 & $*$ & -0.177 & $\mathrm{~ns}$ & 0.443 & $* *$ \\
\hline $\mathrm{pH}$ & 0.001 & $\mathrm{~ns}$ & 0.196 & $\mathrm{~ns}$ & -0.188 & $\mathrm{~ns}$ \\
\hline Turbidity & 0.095 & $\mathrm{~ns}$ & -0.097 & $\mathrm{~ns}$ & 0.037 & $\mathrm{~ns}$ \\
\hline $\mathrm{N}-\mathrm{NH}_{4}{ }^{+}$ & -0.167 & $\mathrm{~ns}$ & 0.256 & $\mathrm{~ns}$ & -0.082 & $\mathrm{~ns}$ \\
\hline $\mathrm{N}^{-\mathrm{NO}_{3}}{ }^{-}$ & -0.628 & $* * *$ & 0.231 & $\mathrm{~ns}$ & -0.625 & $* * *$ \\
\hline $\mathrm{P}_{-} \mathrm{PO}_{4}^{-3}$ & 0.090 & $\mathrm{~ns}$ & 0.098 & $\mathrm{~ns}$ & 0.131 & $\mathrm{~ns}$ \\
\hline Species number & - & - & -0.242 & $\mathrm{~ns}$ & 0.759 & $* * *$ \\
\hline Abundance & - & - & - & - & -0.357 & $* *$ \\
\hline
\end{tabular}

\section{Discussion}

As Vam Co Tay and Vam Co Dong Rivers are located in tropical region, the water temperature in the rivers was within the range of $28-32^{\circ} \mathrm{C}$ which was similar to water temperature of some other water bodies in Southern Vietnam (Dao 2010; Pham et al. 2015). However, temperature in Vam Co River was quite lower than that in Red River from Northern Vietnam, which was around $24^{\circ} \mathrm{C}$ (Duong et al. 2014a). The average water temperature of around $30^{\circ} \mathrm{C}$ from Vam Co River is favorable conditions for development of phytoplankton (Wetzel 2001). Although being a running water body, Vam Co Tay River had the water $\mathrm{pH}$ of slight acid to neutral, which was comparable to the $\mathrm{pH}$ in Tri An reservoir (Dao 2010), and much lower than the turbidity in Red River (Duong et al. 2014a). Interestingly, the pH in Vam Co Dong river was acid characteristic (Table 2) and again was much lower than the $\mathrm{pH}$ in Red River in Northern Vietnam (Duong et al. 2014a). The low pH condition of the water should strongly contribute to the high water transparency or low turbidity ( $2-32$ NTU, in case of Vam Co Dong river) which was clearly showed in the in situ measurement (Table 2).

The nitrate and ammonium concentrations in the Vam Co Dong and Vam Co Tay Rivers were within the range of, or higher than these inorganic nitrogen concentrations from many different lakes and rivers in the world (4-800 $\mu \mathrm{g} / \mathrm{L}$; Horne and Goldman 1994), and not as high as that in Red River, ranging from $286-1028 \mu \mathrm{g} / \mathrm{L}$ (Duong et al. 2014a). The inorganic nitrogen concentration of less than $0.1 \mathrm{mg} / \mathrm{L}$ may limit growth of phytoplankton (Horne and Goldman 1994). Hence nitrogen concentration at most sampling sites, except site 1 at Moc Hoa Town, in Vam Co River should be sufficient for development of phytoplankton.

Reynolds (2007) reported that total phosphorus concentration of $0.01-0.035 \mathrm{mg} / \mathrm{L}$ characterized for mesotrophic condition and that of $0.035-0.10 \mathrm{mg} / \mathrm{L}$ did for eutrophic 
condition. The phosphate (as $\mathrm{P}-\mathrm{PO}_{4}{ }^{3-}$ ) concentration in Vam Co River ranged from $0.02-$ $0.37 \mathrm{mg} / \mathrm{L}$ (Table 2), and total phosphorus concentration should be higher than phosphate concentration. Therefore, the Vam Co Dong and Vam Co Tay rivers should be characterized for mesotrophic and eutrophic conditions, respectively, in term of phosphorus during the monitoring in 2011. So the environmental conditions in Vam Co River during were favorable for development of phytoplankton.

In Vietnam, there were more investigations and publications on phytoplankton in lakes and reservoirs than in rivers. Dao (2010) recorded 197 species of phytoplankton during 1 year monitoring in Tri An Reservoir in which green algae contributed highest species number to the phytoplankton community. Through out 12 months of sampling in Tuyen Lam reservoir, 43 phytoplankton species were reported in which green algae was also dominant in species number (Tran et al. 2015). In the current study, Diatoms were dominant in species number in February, May, July and August but the most diversified group phytoplankton was occupied by green algae in October and December (Table 3). For the whole year of monitoring, green algae contributed highest number of species. This should be related to the water characteristics of the Vam Co River, strongly influenced in rainy season by water source from the inland. However, phytoplankton communities in the mentioned reservoirs and Vam Co River shared the same phytoplankton groups of cyanobacteria, yellow algae, golden algae, green algae, diatoms, euglenoids and dinoflagellates.

They were freshwater species and well developed in rich nutrient conditions. Besides, the dominant of Microcystis spp. at some sites should be paid attention because of their potential harmful effects during their mass development. Duong et al. (2014b) observed the dominance of several phytoplankton species from Hoa Binh resevoir, Northern Vietnam, including species of green algae, cyanobacteria, Diatoms, euglenoids and dinoflagellates. The difference on the dominant species between the observation of Duong et al. (2014), (mainly with green algae and cyanobacteria), and our study (mainly Diatoms) should be related to the types of water bodies. Duong et al. (2013) investigated phytoplankton in a reservoir, more or less still water which was favorable condition for cyanobacteria and green algae development, whereas the current study was implemented in a running water condition which was more suitable for Diatoms growth.

In general, phytoplankton densities during the monitoring were not very high, below 100000 individuals/L. Although some environmental conditions such as temperature and nutrients from Vam Co River were favorable for phytoplankton development as mentioned above, their densities were not high in the river. In nature, the growth of phytoplankton is regulated by multi-factors rather than by a single parameter (Dao 2010). Phytoplankton developed faster in still water and slower in running water (Wetzel 2001). These low phytoplankton densities could be related to the high water current in Vam Co River which needs further investigation especially the monitoring on the water current to confirm. The densities sharply increased at site 5 (Moi bridge) in February and May, at site 9 (Thu Thua creek - Vam Co Dong) and site 12 (Doi Ma creek) in May 2011 (Fig. 3). The dominant species at these sites in February and May were Cyclotella stylorum and Oscillatoria sp. The species C. stylorum originated from estuary and coastal region whereas Oscillatoria sp. could live in a wide range of salinity. 
Hence, the increase of densities could be the result of tide effects which brought high density of C. stylorum from estuary area into the sites 5, 9 and 12 .

The bio-diversity index values were characterized for oligotrophic to eutrophic conditions of the aquatic environment. Generally, the biodiversity index values were lower in dry season (February, May) and higher in the remaining time of the year (July - December, Table 4). Besides, the values seemed to be higher at the sites in up stream. Those should be related to the water current which was stronger in rainy season and more artificial impacts by human beings' activities in the down stream of the river. Generally the Diatomeae index values in the sampling sites during the monitoring from Vam Co River were more than 0.2, indicating that the water quality of sampling sites was eutrophic according to Nguyen (2003).

\section{Conclusion}

During the six monitoring times in 2011 in Vam Co River, the nutrients including inorganic nitrogen and phosphate concentrations were characterized for mesotrophic to eutrophic conditions. Besides, some physical variables such as temperature and turbidity were favorable for development of phytoplankton. There were 290 algal species belonging to 7 groups of phytoplankton, cyanobacteria, yellow algae, golden algae, green algae, diatoms, euglenoids and dinoflagellates, in the studied areas of which green algae and diatoms were dominant in species number. Generally, phytoplankton densities during the monitoring were not very high which could be resulted by the high water current in Vam Co River which needs further investigation. The values of algal biodiversity index and Diatomeae index reflected the oligotrophic condition in the upstream sampling sites and eutrophic condition in the downstream sites. Species number of phytoplankton positively correlated with temperature and negatively correlated with nitrate concentration in water. Additionally, the phytoplankton biodiversity positively correlated with water temperature and species number, but it negatively correlated with nitrate concentration and phytoplankton abundance. Results of this study contribute the interesting information on phytoplankton composition and abundance, their correlation with environmental parameters and environmental characteristics, in running water which is quite limited in Southern Vietnam. Besides, the results confirm the advantage of using phytoplankton and their indices as useful tools for environmental monitoring and water quality assessment.

\section{Acknowledgement}

We would like to thank Ms. Vo Thi My Chi for helping with the sampling map.

\section{References}

APHA (2005). Standard methods for the examination of water and wastewater. American Public Health Association, Washington DC., USA.

Bourrelly, P. (1970). Les algues d'eau douce - Tom III: Les algues bleues et rouges - Les Eugléniens, Peridiniens et Cryptomonadines. Boubée et Cie, Paris, 512 pp.

Cimdins, P., Druvietis, I., Liepa, R., Parele, E., Urtane, L., \& Urtans, A. (1995). A Latvian catalogue of indicator species of freshwater saprobity. Proceeding of the Latvian academy of 
sciences, Sec. B, no.1/2 (570/571), 122-133.

Dao, T. S. (2010). Toxicity of cyanobacteria and cyanobacterial compounds from Tri An reservoir, Vietnam, to daphnids. PhD Dissertation, Humboldt University, Berlin.

Duong, T. T., Le, T. P. Q., Dao, T. S., Pflugmacher, S., Rochelle-Newall, E., Hoang, T. K., Vu, T. N., Ho, C. T., \& Dang, D. K. (2013). Seasonal variation of cyanobacteria and microcystins in the Nui Coc Reservoir, Northern Vietnam. Journal of Applied Phycology 25, 1065-1075. http://dx.doi.org/10.1007/s10811-012-9919-9

Duong, T. T., Le, T. P. Q., Ho, T. C., Vu, T. N., Hoang, T. T. H., Dang, D. K., Lu, X. (2014a). Phytoplankton community structure and water quality of Red river, Vietnam. J. Viet. Environ. 6(1), 27-33.

Duong, T. T., Vu, T. N., Le, T. P. Q., Ho, T. C., Hoang, T. K., Nguyen, T. K., Dang, D. K. (2014b). Seasonal variation of phytoplankton assemblage in Hoa Binh reservoir, north of Vietnam. J. Viet. Environ. 6(1), 22-26.

Horne, A. J., \& Goldman, C. R. (1994). Limnology. McGraw-Hill Inc., 571pp. DOI: $10.4319 / 10.1984 .29 .2 .0447 b$

Kelly, M. G., \& Whitton, B. A. (1995). The eutrophic diatom index: a new index for monitoring eutrophication in rivers. Journal of Applied Phycology 7, 433-444. http://dx.doi.org/10.1007/BF00003802

Komárek, J., \& Anagnostidis, K. (1989). Modern approach to the classification system of cyanophytes. 4. Nostocales. Arch. Hydobiol. Suppl. 82/Algol. Stud. 56, 247-345.

Komárek, J., \& Anagnostidis, K. (1999). Cyanoprokaryota 1. Teil: Chroococcales. In Büdel, B., Gärtner, G., Krienitz, L., Schagerl, M. (Eds): Süßwasserflora von Mitteleuropa. 19/1: 1-548. Gustav Fischer Verlag Jena.

Komárek, J., \& Anagnostidis, K. (2005). Cyanoprokaryota 1. Teil: Oscillatoriales. In Büdel, B., Gärtner, G., Krienitz, L., Schagerl, M. (Eds): Süßwasserflora von Mitteleuropa. 19/2: 1-759. Gustav Fischer Verlag Jena.

Krammer, K., \& Lange-Bertalot, H. (2004a). Süßwasserflora von Mitteleuropa, Bacillariophyceae 3. Teil: Centrales, Fragilariaceae, Eunotiaceae. Gustav Fischer Verlag Jena, $598 \mathrm{pp}$.

Krammer, K., \& Lange-Bertalot, H. (2004b). Süßwasserflora von Mitteleuropa, Bacillariophyceae 4. Teil: Achnanthaceae. Gustav Fischer Verlag Jena, 468 pp.

Le, C. L. (2009). Studying the currents of Vam Co river. Journal of Research and Development, 2, 67-76.

Nguyen, T. T. (1997). The freshwater algae of Nam Cat Tien National Park. Bulletin of Natural Sciences, No. 1. College of Natural Sciences, Vietnam National University - Ho Chi Minh City, 57-72. 


\section{Macrothink}

Nguyen, V. T. (2003). Biodiversity of algae in the inland water bodies of Vietnam - prospects and challenges. Agricultural Publishing House, Vietnam.

Nguyen T. T. L., Cronberg, G., Larsen, J., \& Moestrup, O. (2007). Planktic cyanobacteria from freshwater localities in Thuathien-Hue Province, Vietnam I. Morphology and distribution. Nova Hedwigia, 85, 1-34. http://dx.doi.org/10.1127/0029-5035/2007/0085-0001

Pham, H. H. (1969). Quelques algues d'eau douce de la région de Cantho. Annals of the University of Cantho. Science and Agriculture, 35-59.

Pham, T. L., Dao, T. S., Shimidu, K., Do-Hong, L. C., \& Utsumi, M. (2015). Isolation and characterization of microcystin-producing cyanobacteria from Dau Tieng reservoir, Vietnam. Nova Hedwigia 191, 3-20. http://dx.doi.org/10.1127/nova_hedwigia/2014/0243

Phung, T. N. H., Couté, A., Bourrelly, P. (1992). Les Cyanophycées du delta du Mékong (Vietnam). Nova Hedwigia, 54, 403-446.

Prescott, G. W. (1951). Algae of the Western Great Lakes area - exclusive Desmids and Diatoms, Cranbook Institute of Science. http://dx.doi.org/10.2307/1438342

Reynolds, C. S. (2006). Ecology of phytoplankton. Cambridge University Press, 535. http://dx.doi.org/10.1017/cbo9780511542145

Saad, M., El-Karim, A. (2015). Survey to compare phytoplankton functional approaches: how can these approaches assess river Nile water quality in Egypt? Egyptian Journal of Aquatic Research, 41, 247-255. http://dx.doi.org/10.1016/j.ejar.2015.07.002

Sournia, A. (1978). Phytoplankton manual, UNESCO, UK. http://dx.doi.org/10.1002/iroh.19800650312

Tran, T.T., Doan, N.H., Le, B.D. (2015). Seasonal variation of phytoplankton in Tuyen Lam reservoir in Da Lat, Vietnam. Vietnam Journal of Biology, 37, 414-425. DOI: $10.15625 / 0866-7160 / \mathrm{v} 37 \mathrm{n} 4.6650$

Wetzel, R. G. (2001). Limnology: lake and river ecosystems ( $3^{\text {rd }}$ edition). Academic Press, San Diego, 205-288, 331-393.

\section{Copyright Disclaimer}

Copyright for this article is retained by the author(s), with first publication rights granted to the journal.

This is an open-access article distributed under the terms and conditions of the Creative Commons Attribution license (http://creativecommons.org/licenses/by/3.0/). 